\title{
Does excess weight cause osteoarthritis and, if so, why?
}

\author{
David T Felson
}

Osteoarthritis is a slowly evolving degenerative disease affecting cartilage and bone. Like other chronic non-infectious diseases, its aetiology appears to be multifactorial and therefore preventable by risk factor modification. One of the best studied potentially modifiable risk factors is obesity. While this review will use the concepts of adiposity and weight interchangeably, it should be recognised that these are biologically different phenomena, one representing an increase in adipose tissue and the other representing increased force across weight bearing joints.

Risk factors for osteoarthritis are different, depending on which joint is affected. ${ }^{1}$ Knee injuries, like those sustained in football, predispose to knee osteoarthritis but obviously not to hand osteoarthritis. Some factors may have purely local effects, whereas others have systemic effects. The effects of weight (or adiposity) may be both local and systemic.

\section{Excess weight and the risk of knee} osteoarthritis

Population based studies of osteoarthritis have consistently shown that overweight persons are at higher risk of having knee osteoarthritis than non-overweight controls. Estimates of risk vary and depend to some degree on both the criteria for overweight and the definition of osteoarthritis. In data from the first National Health and Nutrition Examination Survey conducted throughout the United States in 1971-1975, ${ }^{2}$ obese women (body mass index (BMI) greater than 30 , yet $\leq 35$ ) had almost four times the risk of osteoarthritis as women whose BMI was under 25. For men in the same overweight category (BMI greater than 30, yet $\leq 35$ ), the risk was increased 4.8 -fold over men who were of normal weight. These risk estimates are similar to those found in other studies. Three to six times body weight is exerted across the knee during single leg stance in walking. Therefore any increase in weight may be roughly multiplied by this factor to reveal the excess force across the knee when an overweight person walks.

While studies have shown a cross sectional association of obesity and osteoarthritis, there was the possibility that the persons who were overweight gained weight after developing osteoarthritis because of their knee pain and sedentary level of activity. Recent studies, however, have disproved this notion, showing that being overweight at an average age of 37 years, when osteoarthritis of the knee is extremely uncommon, increased the risk of developing knee osteoarthritis in people in their 70s. ${ }^{3}$ Also, repeated $x$ rays of persons in population studies have now shown that baseline weight in a person without osteoarthritis is a potent factor affecting their risk of knee osteoarthritis later. ${ }^{45}$

Several other features of the association between obesity and knee osteoarthritis are noteworthy. First, obese persons appear to be at an especially high risk of bilateral knee osteoarthritis as opposed to unilateral disease, the latter of which may be more often associated with knee injury. Second, this strong association is not attenuated by adjustment for other factors correlated with obesity ${ }^{6}$ such as hyperlipidaemia, hyperuricaemia, and diabetes, and it is unexplained by distribution of adipose tissue in the body. Lastly, in some studies the relation between obesity and knee osteoarthritis has been stronger in women than in men..$^{3-5}$ Obese women have an especially high risk of knee osteoarthritis, whereas obese men have a marginally higher risk than non-obese men. Some of the sex difference may be explained by the tendency for thin men to have a history of an osteoarthritis inducing knee injury.

\section{Excess weight and the risk of hip osteoarthritis}

Overweight persons have a higher than expected risk of hip osteoarthritis, although the association of weight with hip osteoarthritis in most studies is not as strong as with knee osteoarthritis. Studies (see the table) have been inconsistent, with some even reporting no association. ${ }^{7-12}$ Studies that include a large number of hip osteoarthritis cases ${ }^{914}$ have tended to suggest an association between obesity and hip osteoarthritis.

Two published studies ${ }^{1114}$ and a third, as yet unpublished (Nevitt $\mathrm{M}$ et al, unpublished data), have suggested that obese persons have an especially high risk of bilateral hip osteoarthritis but not of unilateral disease. In over 5000 women with hip $x$ rays from the Study of Osteoporotic Fractures, obesity was associated with an $80 \%$ increase in the odds of bilateral hip osteoarthritis (odds ratio $=1.8$ ) but only a $40 \%$ increase in unilateral osteoarthritis (odds ratio $=1.4$ ).

Differences in disease definition may explain study differences. Those studies focusing on only radiographic disease have inconsistently reported an association of obesity with hip osteoarthritis, whereas studies with symptomatic hip osteoarthritis or clinical disease as a case definition have, in general, reported an association. ${ }^{13-15}$ The association of obesity with symptomatic hip osteoarthritis could be
Arthritis Center, A203, Boston, MA 02118, USA

D T Felson 


\begin{tabular}{|c|c|c|c|c|c|c|c|}
\hline $\begin{array}{l}\text { Ref } \\
\text { No }\end{array}$ & Authors (year) & $\begin{array}{l}\text { Total } \\
\text { cases }\end{array}$ & Sex & Disease definition & General findings & $\begin{array}{l}O R(95 \% \\
C I) \text { for } \\
\text { association } \\
\text { with bilateral } \\
O A\end{array}$ & $\begin{array}{l}\text { OR }(95 \% \\
\text { CI) for } \\
\text { association } \\
\text { with } \\
\text { unilateral } O A\end{array}$ \\
\hline 7 & Keligren $(1961)^{7}$ & $379(46)$ & Both & Radiographic & $\begin{array}{l}\text { Obese and non-obese with } \\
\text { equal prevalence OA }\end{array}$ & NT & NT \\
\hline 8 & $\begin{array}{l}\text { Saville and } \\
\text { Dickson }(1968)^{8}\end{array}$ & $\begin{array}{l}121 \\
(121)\end{array}$ & Both & Clinical & $\begin{array}{l}\text { Mean weight } O A=\text { mean } \\
\text { weight in population }\end{array}$ & NT & NT \\
\hline 9 & Kraus et al (1978) ${ }^{9}$ & $\begin{array}{l}200 \\
(100)\end{array}$ & Both & Severe clinical & $\begin{array}{l}\text { Increased risk of } \mathrm{OA} \text { in } \\
\text { obese }(R R=2.7, P<0.005)\end{array}$ & NT & NT \\
\hline 10 & $\begin{array}{l}\text { Hartz et al } \\
\text { (1986) } 10 \\
\text { (NHANES I) }\end{array}$ & $\begin{array}{l}4225 \\
(59)\end{array}$ & Both & Radiographic & $\begin{array}{l}\text { Increased relative weight in } \\
\text { those with OA }\end{array}$ & NT & NT \\
\hline 11 & $\begin{array}{l}\text { Tepper and } \\
\text { Hochberg }(1993)^{11} \\
\text { (NHANES I) }^{\text {NHAN }}\end{array}$ & $\begin{array}{l}2490 \\
(73)\end{array}$ & Both & Radiographic & $\begin{array}{l}\text { Overweight (by BMI) } \\
\text { unassoc. with } \mathrm{OA} \\
(\mathrm{OR}=1.02)\end{array}$ & $\begin{array}{l}2.0 \\
(0.97,4.2)\end{array}$ & $0.5(0.3,1.2)$ \\
\hline 12 & $\begin{array}{l}\text { Van Saase et al } \\
(1988)^{12}\end{array}$ & $\begin{array}{l}2168 \\
(122)\end{array}$ & Both & Radiographic & $\begin{array}{l}\text { In obese men } O R \text { for } O A \\
=2.59 ; \text { for obese women, } O R \\
\text { for } O A=0.40\end{array}$ & NT & NT \\
\hline 13 & Vingard $(1991)^{13}$ & $\begin{array}{l}569 \\
(247)\end{array}$ & Men & $\begin{array}{l}\text { THR patients } \\
\text { (clinical) }\end{array}$ & $\begin{array}{l}\text { For overweight at age } 40 \mathrm{OA} \\
\text { risk increased } \\
(\mathrm{OR}=3.5(1.4,4.5))\end{array}$ & NT & NT \\
\hline \multirow[t]{2}{*}{14} & $\begin{array}{l}\text { Heliovaara et al } \\
(1993)^{14}\end{array}$ & $\begin{array}{l}7217 \\
(369)\end{array}$ & Both & Clinical & $\begin{array}{l}\text { Heaviest persons with } \\
\text { increased risk of hip OA } \\
(\mathrm{OR}=2.0)\end{array}$ & $\begin{array}{l}\text { BMI 30-35: } \\
2.3(1.5,3.5)\end{array}$ & $1.6(1.0,2.5)$ \\
\hline & & & & & & $\begin{array}{l}\mathrm{BMI}>35 \\
2.8(1.4,5.7)\end{array}$ & $1.0(0.5,3.0)$ \\
\hline 15 & $\begin{array}{l}\text { Roach et al } \\
(1994)^{15}\end{array}$ & $332(99)$ & Men & Clinical & $\begin{array}{l}\text { Obese with higher risk of hip } \\
\text { OA }(O R=2.0 ;(1.0,4.0))\end{array}$ & NT & NT \\
\hline
\end{tabular}

NT, not tested; OR, odds ratio; CI, confidence interval; BMI, body mass index.

explained by an effect of obesity on inducing hip symptoms in those with structural disease. Alternatively, the failure to detect an association of obesity with radiographic osteoarthritis could reflect the imprecision of radiographic diagnoses of hip osteoarthritis and suggest that clinical hip osteoarthritis more validly reflects disease pathology.

Not only are overweight persons at high risk of developing knee osteoarthritis, but increasingly, longitudinal studies suggest that overweight persons with knee osteoarthritis are at high risk of disease progression ${ }^{16}$ and that women with unilateral disease who are overweight may be at a much higher risk of developing bilateral knee osteoarthritis than their non-overweight counterparts. ${ }^{17}$

\section{Excess weight and the risk of hand osteoarthritis}

Surprisingly, people who are overweight also appear to be at higher risk of hand osteoarthritis than those who are not overweight.

A recent longitudinal study over 23 years showed that those who were overweight had a higher risk of developing hand osteoarthritis than those who were not. ${ }^{18}$ While cross sectional studies of the relation between overweight and hand osteoarthritis have not all been positive, most suggest an association. Since overweight persons do not necessarily have greater force across their joints than those who are not overweight, the relation between overweight and osteoarthritis remains enigmatic.

\section{Mechanisms by which obesity could cause osteoarthritis}

Weight could act through two different intermediaries to cause osteoarthritis. First, and most logically, being overweight - because it increases the amount of force across a joint - could induce cartilage breakdown simply on the basis of excess force, which then leads to osteoarthritis. While this explanation may go a long way towards explaining the apparent causal relation of weight to knee osteoarthritis and the association of being overweight with an increased risk of hip osteoarthritis, it may not explain the relation between overweight and developing hand osteoarthritis. To do this one needs to invoke a systemic factor. Following this line of reasoning, persons who are overweight may have a circulating factor, possibly a cartilage growth factor or a bone factor that may act to accelerate cartilage breakdown and lead to osteoarthritis. Adipose tissue could be the source of an endocrine factor, especially in postmenopausal women who are at highest risk of osteoarthritis. In addition, overweight persons have higher bone mineral densities, and high bone mineral density (or the absence of osteoporosis) may itself be a risk factor for osteoarthritis. ${ }^{19}$ Additional evidence in favour of a systemic factor is the possibility that the relation between overweight and osteoarthritis is stronger in women than men. In favour of the load theory is the stronger association of obesity with osteoarthritis of the knee, where the load multiplication factor for overweight is great. The stress (or force per unit area) of weight on the knee could be greater than the stress of weight on the hip, where force could be more widely distributed.

\section{Weight loss in the prevention of osteoarthritis}

In the Framingham study where subjects have been studied biennially for 40 years with weights measured, Felson et $a l^{20}$ evaluated whether weight loss or weight gain affected the risk of incident symptomatic knee osteoarthritis in women. For women whose baseline BMI values were at least 25 (above the median), 
weight loss lowered the rate of knee osteoarthritis. The adjusted odds ratio per two units of BMI (approximately $5 \mathrm{~kg}$ for a women of normal height) was 0.41 , a reduction of more than $50 \%$ in the risk of developing knee osteoarthritis $(P=0.02)$. Weight gain was associated with a slightly increased rate of later knee osteoarthritis (odds ratio 1.28 for a two unit weight gain). For women whose baseline weight was under the median, neither weight gain nor weight loss significantly affected their risk of later disease.

How much disease might be prevented if overweight persons lost weight? Using data from the Framingham osteoarthritis study, ${ }^{21}$ osteoarthritis was defined by the presence of symptoms and radiographs showing osteoarthritis. If men whose BMI was at least 30 lost enough weight to fall into the overweight category (BMI 26-29.9) and men in the overweight category lost enough weight to move in the reference range (BMI $<26$ ), the rate of symptomatic knee osteoarthritis in men would decrease by $21.4 \%$. This drop in osteoarthritis rates would be even greater if men with BMIs $\geq 30$ were able to lose enough weight to fall into the reference range (BMI $<26)$. For women, if those in the highest weight group (for women, $B M I \geq 29$ ) dropped into the overweight group (BMI of 25-28.9) and those in the overweight category dropped into the reference group (BMI < 25) the total rate of knee osteoarthritis would decrease by $33 \%$. For women, weight accounts for more osteoarthritis than any other known factor; for men, overweight is second to major knee injury as a preventable cause of knee osteoarthritis.

\section{Weight loss as a treatment for osteoarthritis}

There is an unfortunate a lack of data on weight loss as a treatment for osteoarthritis. One uncontrolled natural experiment occurred when a large group of morbidly obese patients underwent gastric stapling operations and were assessed before and after the operation. ${ }^{22}$ It should be noted that these patients did not necessarily have osteoarthritis, although many had joint pains in the knees and back. At one year after surgery, with a 100 pound $(45.5 \mathrm{~kg})$ weight loss on average, symptoms in the knees, hips, and other joints were much less frequent than before. For example, $57 \%$ of subjects had knee pain before surgery versus a $14 \%$ prevalence of knee pain afterwards. This impressive result suggests that patients with osteoarthritis who are overweight will experience symptomatic relief with weight loss, although the amount of weight loss needed to alleviate symptoms and prevent disease progression is unknown. In a small randomised trial, ${ }^{23}$ persons with clinical knee or hip osteoarthritis were randomised to an appetite suppressant, phentermine, or placebo and all patients participated in weight reduction sessions. While most patients in both groups lost weight and there were no significant differences in joint symptoms at trial's end, weight loss (3-6 kg on average) correlated strongly with reduction in clinical osteoarthritis score, a correlation that was stronger for knee than for hip osteoarthritis. Lastly, people with osteoarthritis who are overweight are often ineligible for total knee and total hip surgeries, procedures that effectively alleviate pain.

\section{Conclusion}

In summary, being overweight is an important modifiable risk factor for osteoarthritis in the knees, hips, and hands. The biological mechanism, while probably related to joint force, is not entirely clear. Weight loss may prevent disease, especially in the knees, and those who are overweight are at high risk of disease progression and are likely to have a progressive disease course. Supported by Multipurpose Arthritis and Musculoskeletal Disease Center Grant
Institutes of Health.

1 Felson D. Epidemiology for knee and hip osteoarthritis. Epidemiol Rev 1988;10:1-28.

2 Anderson J, Felson DT. Factors associated with osteoarthritis of the knee in the First National Health and Nutrition Examination Survey (NHANES I). Am $\mathcal{f}$ Epidemiol 1988 128:179-89.

3 Felson DT, Anderson J, Naimark A, Walker AM, Meenan RF. Obesity and knee osteoarthritis. Ann Intern Med 1988; 109:18-24.

4 Schouten JSAG, van den Ouweland F, Valkenburg HA. A 12 year follow up study in the general population on prognostic factors of cartilage loss in osteoarthritis of the knee. Ann Rheum Dis 1992;51:932-7.

5 Felson DT, Zhang Y, Hannan MT, Weissman B, Aliabadi P. Risk factors for incident $x$-ray OA (osteoarthritis) in the elderly. Arthritis Rheum 1995;38:S396.

6 Davis M, Ettinger WH, Neuhaus JM. The role of metabolic factors and blood pressure in the association of obesity with osteoarthritis of the knee. $\mathcal{F}$ Rheumatol 1988;15:182732.

7 Keligren JH. Osteoarthrosis in patients and populations $B M \mp 1961 ; \mathrm{i}: 1-6$.

8 Saville PD, Dickson J. Age and weight in osteoarthritis of the hip. Arthritis Rheum 1968;11:635-44.

9 Kraus JF, D'Ambrosia RD, Smith EG, Van Meter J Borhani NO, Franti CE, et al. An epidemiological study of severe osteoarthritis. Orthopedics 1978;1:37-42.

10 Hartz AJ, Fischer ME, Bril G, Kelber S, Rupley D, Oken B et al. The association of obesity with joint pain and osteoarthritis in the HANES data. $f$ Chron Dis 1986 49:311-9.

11 Tepper S, Hochberg MC. Factors associated with hip osteoarthritris: data from the First National Health and Nutrioarthritris: data from the First National Health and Nutri-
tion Examination Survey (NHANES-I). Am $₹$ Epidemiol tion Examination

12 van Saase JLCM, Vandenbroucke JP, van Romunde LKJ Valkenburg HA. Osteoarthritis and obesity in the genera population. A relationship calling for an explanation. $f$ Rheumatol 1988;15:1152-8.

13 Vingard E. Work, sports, overweight and osteoarthrosis of the hip. Thesis. Arbete och Halsa. Stockholm: Karolinska Institute, 1991:25

14 Heliovaara M, Mkel M, Impivaara O, Knekt P, Aromaa A Sievers K. Association of overweight, trauma and workload with coxarthrosis: a health survey of 7217 persons. Acta Wrthop Scand 1993;64:513-8.

15 Roach KE, Persky V, Miles T, Budiman-Mak E. Biomechanical aspects of occupation and osteoarthritis of the hip: A case-control study. F Rheumatol 1994;21:2334-40.

16 Dougados M, Gueguen A, Nguyen M, Thiesce A, Listrat V, Jacob L, et al. Longitudinal radiologic evaluation of osteoarthritis of the knee. $\mathcal{F}$ Rheumatol 1992;19:378- 83.

17 Spector TD, Hart DJ, Doyle DV. Incidence and progression of osteoarthritis in women with unilateral knee disease in the general population: the effect of obesity. Ann Rheum Dis 1994;53:565-8.

18 Carman WJ, Sowers MF, Hawthorne VM, Weissfeld LA Obesity as a risk factor for osteoarthritis of the hand and wrist: a prospective study. Am $₹$ Epidemiol 1994;139:11929.

19 Hannan MT, Anderson J, Zhang Y, Levy D, Felson DT Bone mineral density and knee osteoarthritis in elderly men and women. Arthritis Rheum 1993;36:1671-80.

20 Felson DT, Zhang Y, Anthony JM, Naimark A, Anderson JJ Weight loss reduces the risk for symptomatic knee osteoarthritis in women. Ann Intern Med 1992;116:535-9.

21 Felson DT. Weight and osteoarthritis. $\mathcal{f}$ Rheumatol 1995; 22(suppl 43):7-9.

22 McGoey BV, Deitel M, Saplys RJF, Kliman ME. Effect of weight loss on musculoskeletal pain in the morbidly obese. f Bone foint Surg Br 1990;72B:322.

23 Williams RA, Foulsham BM. Weight reduction in osteoarthritis using phentermine. Practitioner 1981;225:231-2. 